\title{
Pengaruh Intellectual Capital terhadap Profitabilitas pada Perusahaan Manufaktur yang Terdaftar di Bursa Efek Indonesia
}

\author{
Ramadhania Intan Cahyani' ${ }^{1}$, Tara Widiarti $\mathrm{S}^{2}$, Jelita Listya Ferdiana ${ }^{3}$ \\ ${ }^{1,2,3}$ STIE Perbanas Surabaya, Jalan Nginden Semolo 34-36 Surabaya 60118. Indonesia.
}

\section{N F O A R T I K E L}

\section{JEL Classification}

G14

G30

\section{Keywords :}

intellectual capital (IC),

VAHU (Value Added Human Capital),

VACA (Value Added Capital Employed),

STVA (Structural Capital Value Added), profitability, ROA (Return On Asset).

\section{A $B$ S $S$ T $R A C A$}

This study aims to determine the effect of Intellectual Capital (IC) on profitability of manufacturing companies listed in Indonesia Stock Exchange (IDX). The independent variable of this study is Intellectual Capital (IC) while the dependent variable is profitability. Intellectual Capital (IC) was measured using VAICTM (Value Added Intellectual Coefficient) method which has 3 indicators, namely VAHU (Value Added Human Capital), VACA (Value Added Capital Employed), and STVA (Structural Capital Value Added). Meanwhile, profitability was measured using ROA (Return On Asset). Purposive sampling method was used in this study. Moreover, the populations involved were companies specializing on manufacturing. The total of samples used was 58 manufacturing companies listed in Indonesia Stock Exchange (IDX) from 2010-2013 period. In addition, Partial Least Square (PLS) was used as data analysis method. The result showed that Intellectual Capital (IC) has significant effect on profitability of manufacturing companies listed in Indonesia Stock Exchange (IDX). Therefore, VAICTM (Value Added Intellectual Coefficient) method can be used as a tool of decision making for stakeholder by integreting Intellectual Capital (IC) in the decision making process.

\section{A B S T R A K}

Penelitian ini bertujuan untuk mengetahui pengaruh Intellectual Capital (IC) terhadap profitabilitas perusahaan manufaktur yang terdaftar di Bursa Efek Indonesia (BEI). Variabel bebas dari penelitian ini adalah Intellectual Capital (IC) sedangkan variabel terikat adalah profitabilitas. Modal intelektual (IC) diukur dengan menggunakan metode VAIC (Value Added Intellectual Coefficient) yang memiliki 3 indikator, yaitu VAHU (Value Added Human Capital), VACA (Value Added Capital Employed), dan STVA (Structural Capital Value Added). Sementara itu, profitabilitas diukur dengan menggunakan ROA (Return On Asset). Metode purposive sampling yang digunakan dalam penelitian ini. Selain itu, populasi yang terlibat perusahaan yang mengkhususkan diri pada manufaktur. Total sampel yang

*Email Korespondensi: ${ }^{1}$ ramadhania.intan93@gmail.com, ${ }^{2}$ tara.widiarti@yahoo.co.id, ${ }^{3}$ jelitalistya@yahoo.co.id 
digunakan adalah 58 perusahaan manufaktur yang terdaftar di Bursa Efek Indonesia (BEI) dari periode 2010-2013. Selain itu, Partial Least Square (PLS) digunakan sebagai metode analisis data. Hasil penelitian menunjukkan bahwa Intellectual Capital (IC) memiliki pengaruh yang signifikan terhadap profitabilitas perusahaan manufaktur yang terdaftar di Bursa Efek Indonesia (BEI). Oleh karena itu, metode VAIC (Value Added Intellectual Coefficient) dapat digunakan sebagai alat pengambilan keputusan bagi stakeholder dengan integreting Intellectual Capital (IC) dalam proses pengambilan keputusan.

\section{Pendahuluan}

Munculnya Intellectual capital (IC) pada awal 1990-an mendapat perhatian lebih dari para akademisi, perusahaan maupun para investor. Intellectual Capital dipandang sebagai pengetahuan yang digunakan dalam menciptakan kekayaan pada perusahaan. Intellectual capital (IC) merupakan bagian dari aset tidak berwujud yang sangat bernilai dimana informasinya juga dibutuhkan oleh pihak eksternal, akan tetapi pengungkapan intellectual capital tidak terdapat dalam laporan keuangan. Intellectual capital juga merupakan salah satu aset yang penting bagi perusahaan berupa aset tidak berwujud. Intellectual Capital juga dikenal sebagai penciptaan nilai (value creation). Meningkatnya tekanan dan tanggung jawab bisnis terhadap para investor dan karyawan menunjukkan bahwa pentingnya perhatian pada penciptaan nilai (value creation) dimana sebagai suatu ukuran yang baru terhadap keberhasilan bisnis. Sehingga tujuan yang diharapkan dari intellectual capital yaitu mampu meningkatkan kemampuan perusahaan dalam jangka panjang yang dapat dicapai melalui investasi pada sumber daya intelektual terutama pada human capital, yang merupakan faktor penciptaan nilai pada bisnis yang semakin modern (Ulum, 2009 : 84).

Pada tahun 1998, ada seorang ahli bernama Pulic yang mengembangkan pengukuran terhadap Intellectual Capital. Namun Pulic tidak mengukur secara langsung Intellectual Capital yang terdapat pada perusahaan, tetapi dia hanya mengajukan suatu ukuran untuk menilai efisiensi dari nilai tambah sebagai hasil dari kemampuan intelektual perusahaan. Pengukuran yang dikembangkan oleh Pulic adalah VAIC ${ }^{\mathrm{TM}}$ (Value Added Intellectual Coefficient). Value added (VA) merupakan suatu indikator yang paling objektif dalam menilai keberhasilan suatu bisnis dan mampu menunjukkan kemampuan perusahaan dalam penciptaan nilai (value creation).

Tujuan utama dalam komponen Value Added Intellectual Coefficient (VAIC ${ }^{\mathrm{TM}}$ ) adalah menciptakan nilai tambah dalam mengetahui ukuran tentang physcal capital (dana-dana keuangan) dan intellectual potential (nilai-nilai yang melekat pada karyawan atas kemampuan yang dihasilkan). Hal ini dinyatakan bahwa kedua tujuan tersebut telah ditunjukkan oleh Value Added Intellectual Coefficient agar dapat dimanfaatkan secara efektif oleh perusahaan. Dalam mengelola aset fisik dan finansial dibutuhkan kemampuan yang handal dari intellectual capital itu sendiri, selain dalam menghasilkan suatu produk yang memiliki nilai tambah juga diperlukan kemampuan dan daya pikir dari karyawan sekaligus mengembangkan berbagai cara dalam mengelola perusahaan dan menjalin hubungan dengan pihak eksternal.

Menurut Reza Gharoie Ahangar (2011) menunjukkan bahwa perusahaan manufaktur yang ada di Iran menggunakan intellectual capital dengan aset fisik yang dimiliki perusahaan dan terbukti mampu meningkatkan profitabilitas serta daya saing antar perusahaan. Sehingga penelitian atas intellectual capital pada perusahaan dapat digunakanmanajemensebagaiinformasitambahan untuk mengetahui keterkaitan intellectual capital terhadap perkembangan perusahaan di masa yang akan datang. Sumber daya manusia pada sektor manufaktur juga memiliki peranan yang penting terhadap aktivitas perusahaan, sehingga perusahaan dapat memperkuat manajemen melalui intellectual capital dalam mencapai keunggulan yang kompetitif. Penggunaan atas intellectual capital yang dimiliki perusahaan tidak hanya untuk menghasilkan pendapatan tetapi juga mampu meningkatkan daya saing melalui aset fisik yang dimiliki perusahaan. 
Selain itu, penelitian menurut Daniel Zeghal dan Anis Maaloul (2010) menyatakan bahwa Value Added Intellectual Coefficient (VAIC $^{\mathrm{TM}}$ ) mempunyai hubungan yang positif dengan kinerja ekonomi, kinerja keuangan, dan kinerja pasar saham. Hal ini dapat memberikan dampak yang positif terhadap perusahaan seperti dapat mengurangi biaya produksi perusahaan dan meningkatkan value creation (penciptaan nilai) bagi perusahaan yang dapat diinformasikan pada para investor serta pemangku kepentingan yang lain.Apabilaperusahaanmampumengurangibiaya produksi, maka perusahaan dapat meningkatkan profitabilitas. Hal ini yang menunjukkan adanya keterkaitan intellectual capital terhadap profitabilitas perusahaan. Sehingga diharapkan perusahaan dapat memaksimalkan pemanfaatan atas intellectual capital yang dimiliki.

Beberapa penelitian menyatakan bahwa perusahaan yang dapat memanfaatkan intellectual capital secara efektif dan efisien dapat menjadi kunci dari kesuksesan perusahaan tersebut dalam memperoleh keunggulan yang kompetitif. Sehingga perusahaan yang memiliki kinerja intellectual capital yang tinggi diharapkan memiliki tingkat profitabilitas yang tinggi. Sehingga penelitian ini akan menguji dan menganalisis "Pengaruh Intellectual Capital terhadap Profitabilitas pada Perusahaan Manufaktur yang Terdaftar di Bursa Efek Indonesia".

\section{Telaah Teori dan Pengembangan Hipotesis}

\section{Stakeholder Theory}

Teori yang mendukung atas penelitian ini adalah stakeholder theory. Stakeholder theory menyatakan bahwa seluruh stakeholder memiliki hak untuk disediakan informasi tentang aktivitas perusahaan yang dapat mempengaruhi keputusan para stakeholder bahkan ketika para stakeholder memilih untuk tidak menggunakan informasi tersebut atau ketika para stakeholder secara langsung dapat berperan dalam kelangsungan hidup perusahaan (Ulum, 2009 : 4).

Pada konsep intellectual capital yang terdapat dalam teori stakeholder dapat dipandang melalui2 bidangyaitubidangetika(moral)maupun bidang manajerial. Bidang etika menyatakan bahwa seluruh stakeholder mempunyai hak untuk diperlakukan secaraadiloleh perusahaan serta para manajer harus mengelola keuntungan perusahaan untuk kepentingan seluruh stakeholder (Ulum, 2009 : 5-6). Ketika manajer dapat mengelola perusahaan secara maksimal, khusunya dalam mengelola value creation, hal ini menunjukkan bahwa manajer telah memenuhi bidang etika dari teori stakeholder (Ulum, 2009 : 6). Pengelolaan yang baik atas seluruh potensi yang dimiliki perusahaan dapat menciptakan value added bagi perusahaan yang dimana mampu mendorong kinerja keuangan perusahaan untuk kepentingan stakeholder.

Sedangkan pada bidang manajerial dari teori stakeholder menyatakan bahwa kemampuan stakeholder dalam mempengaruhi manajemen harus dipandang sebagai fungsi dari tingkat pengendalian stakeholder atas sumber daya yang dibutuhkan perusahaan (Ulum, 2009 : 6). Ketika para stakeholder berusaha untuk mengendalikan sumber daya perusahaan, maka pengendalian atas sumber daya dapat difokuskan untuk meningkatkan kesejahteraan para stakeholder. Kesejahteraan tersebut dapat diwujudkan pada perolehan return yang semakin tinggi yang dihasilkan oleh perusahaan (Ulum, 2009 : 6).

\section{Intellectual Capital (IC)}

Intellectual capital merupakan sumber daya pengetahuan dalam bentuk karyawan, pelanggan, proses atau teknologi yang dimana perusahaan dapat menggunakannya untuk proses penciptaan nilai (value creation) bagi perusahaan (Bukh et al., 2005). Intellectual Capital mencakup tentang pengetahuan karyawan, organisasi dan kemampuan perusahaan dalam menciptakan nilai tambah (value added) dan keunggulan yang kompetitif. Intellectual capital merupakan bagian dari aset tidak berwujud yang memegang peranan penting dalam meningkatkan daya saing perusahaan dan juga dapat dimanfaatkan secara efektif oleh manajemen untuk meningkatkan profitabilitas perusahaan.

Intellectual Capital merupakan landasan 
dasar bagi perusahaan untuk berkembang serta memiliki keunggulan yang kompetitif dibandingkan perusahaan lain. Intellectual Capital dapat dibentuk melalui tiga kategori yaitu pengetahuan yang berhubungan dengan karyawan yang disebut human capital, pengetahuan yang berhubungan dengan pelanggan yang disebut customer atau relational capital, dan pengetahuan yang behubungan dengan perusahaan yang disebut structural atau organizational capital (Ulum, 2009 : 23).

\section{Value Added Intellectual Coefficient (VAIC ${ }^{T M}$ )}

Value Added Intellectual Coefficient (VAIC ${ }^{\mathrm{TM}}$ ) pertama kali dikembangkan oleh Pulic pada tahun 1998. Value Added Intellectual Coefficient (VAIC ${ }^{\mathrm{TM}}$ )digunakanuntukpengukuran intellectual capital secara tidak langsung dalam mengukur efisiensi nilai tambah (Value Added - VA) pada suatu perusahaan. VAIC ${ }^{\mathrm{TM}}$ (Value Added Intellectual Coefficient) dirancang untuk menyajikan informasi tentang value creation efficiency dari aset berwujud (tangible asset) dan aset tidak berwujud (intangible asset) yang dimiliki oleh perusahaan (Ulum, 2009 : 86-87). Metode Value Added Intellectual Coefficient (VAIC ${ }^{\mathrm{TM}}$ ) relatif mudah untuk digunakan, karena menggunakan data dari akun-akun yang berada di dalam laporan keuangan perusahaan seperti neraca, laba rugi, dan catatan atas laporan keuangan (Ulum, 2009 : 86-87).

Value Added (VA) dianggap indikator paling objektif dalam menilai keberhasilan bisnis serta dapat menunjukkan kemampuan perusahaan dalam penciptaan nilai (value creation). Value Added (VA) dapat dihitung melalui selisih antara output dan input. Value Added (VA) dapat dipengaruhi oleh efisiensi dari Human Capital (HC), Structural Capital (SC), dan Capital Employed (CE). Output (OUT) mencakup pendapatan (revenue) dan seluruh produk dan jasa yang dijual, sedangkan input (IN) mencakup seluruh beban dan biaya yang digunakan dalam memperoleh pendapatan (revenue) kecuali beban karyawan (labour expenses). Beban karyawan tidak termasuk dalam input (IN) karena menurut model Pulic tenaga kerja dianggap sebagai entitas penciptaan nilai atau value creating entity (Ulum, 2009 : 87). Perhitungan untuk VAIC ${ }^{\text {TM }}$ (Value Added Intellectual Coefficient) lebih memfokuskan pada beban karyawan dikarenakan dalam konsep utama dari VAIC ${ }^{\mathrm{TM}}$ (Value Added Intellectual Coefficient) menyatakan bahwa manusia yang memiliki potensi pengetahuan yang tinggi bertanggung jawab terhadap keberhasilan dan kinerja selama berada di dalam suatu perusahaan.

\section{Pengukuran Intellectual Capital (IC)}

Pengukuran VAIC ${ }^{\mathrm{TM}}$ (Value Added Intellectual Coefficient) melalui penjumlahan dari tiga komponen yaitu VAHU (Value Added Human Capital), VACA (Value Added Capital Employee), dan STVA (Structural Capital Value Added). Dan ketiga komponen pembentuk VAIC $^{\mathrm{TM}}$ (Value Added Intellectual Coefficient) dapat diukur sebagai berikut:

\section{a. Value Added Human Capital (VAHU)}

Human capital menunjukkan kemampuan yang dimiliki karyawan dalam memberikan solusi, berinovasi, dan melakukan perubahan positif di dalam persaingan lingkungan kerja. Sehingga, Value Added Human Capital (VAHU) merupakan salah satu pengukuran intellectual capital yang menunjukkan berapa banyak Value Added (VA) dapat dihasilkan dengan dana yang dikeluarkan untuk tenaga kerja. Hubungan antara VA (value added) dan HC (human capital) mengindikasikan kemampuan dari Human Capital dalam menciptakan nilai di dalam perusahaan, dengan kata lain rasio ini menunjukkan kontribusi yang dibuat oleh setiap rupiah yang diinvestasikan dalam HC (Human Capital) terhadap value added (VA) perusahaan (Ulum 2009 : 87-88). VAHU (Value Added Human Capital) dapat dihitung dengan mencari hasil dari VA (value added) yang didapat dari selisih OUT (output) dan IN (input), kemudian dibagi dengan Human Capital (HC) yang merupakan beban karyawan.

\section{b. Value Added Capital Employee (VACA)}

Value Added Capital Employee (VACA) adalah indikator untuk VA (value added) yang diciptakan oleh satu unit dari physical capital - modal fisik 
dan rasio ini menunjukkan kontribusi yang dibuat oleh setiap unit dari capital employed (CE) terhadap value added (VA) perusahaan (Ulum, 2009 : 87). VACA (Value Added Capital Employee) merupakan kemampuan perusahaan dalam mengelola sumber daya berupa capital asset yang apabila dikelola dengan baik akan meningkatkan kinerja keuangan perusahaan (Kartika and Hatane, 2013). VACA (Value Added Capital Employee) dapat dihitung dengan mencari nilai VA yang merupakan selisih antara OUT (output) dan IN (input), kemudian dibagi dengan Capital Employed (CE) yang merupakan ekuitas.

\section{c. Structural Capital Value Added (STVA)}

Structural Capital Value Added (STVA) merupakan suatu pengukuran dari efisiensi SC (structural capital). STVA (Structural Capital Value Added) mengukur jumlah structural capital yang dibutuhkan dalam menghasilkan satu rupiah dari value added dan merupakan indikasi atas keberhasilan SC dalam penciptaan nilai atau value creation (Ulum, 2009 : 88). Nilai yang terdapat pada structural capital tergantung pada nilai human capital. Semakin besar nilai human capital, maka semakin kecil nilai SC (structural capital) yang akan dihasilkan. Sebaliknya, semakin kecil nilai human capital maka semakin besar nilai SC (structural capital) yang dihasilkan. Hal ini dikarenakan nilai SC (structural capital) diperoleh dari selisih antara VA (value added) dan HC (human capital).

\section{Profitabilitas}

Profitabilitas merupakan suatu pengukuran atas kemampuan perusahaan dalam menghasilkan atau meningkatkan laba. Profitabilitas dapat mencerminkan tingkat efektivitas yang dicapai oleh suatu perusahaan. Beberapa fenomena menunjukkan bahwa perusahaan yang memiliki keuntungan atas operasi perusahaan yang dilakukan cenderung menyampaikan laporan keungan secara tepat waktu. Sebaliknya, beberapa fenomena juga menunjukkan bahwa perusahaan yang mengalami penurunan atas profitabilitas atau mengalami kerugian cenderung terlambat menyampaikan laporan keuangan.

Terdapat beberapa indikator yang digunakan dalam mengukur profitabilitas yaitu rasio profit margin, return on asset, dan return on equity. Dalam penelitian ini profitabilitas diukur dengan menggunakan rasio return on asset (ROA), dimana menghubungkan antara laba yang diperoleh dari kegiatan pokok atau aktivitas perusahaan dengan aset yang dimiliki untuk menghasilkan pendapatan serta keuntungan bagi perusahaan. ROA (return on asset) merupakan salah satu indikator keberhasilan perusahaan dalam menghasilkan laba sehingga semakin tinggi profitabilitas maka semakin tinggi kemampuan perusahaan untuk menghasilkan laba (Rachmawati, 2012).

\section{Pengaruh Intellectual Capital terhadap Profitabilitas}

Intellectual Capital (IC) merupakan bagian dari aset tidak berwujud tetapi memiliki peran yang penting pada suatu organisasi atau perusahaan. Tidak mudah mengukur Intellectual capital secara langsung. Sehingga, pada tahun 1998 seorang peneliti bernama Pulic mengembangkan metode pengukuran atas intellectual capital secara tidak langsung. Metode yang dikembangkan berfokus pada nilai tambah (value added) yang dimiliki oleh perusahaan. Nilai tambah dapat dihasilkan melalui human capital, capital employed, dan structural capital yang merupakan sumber daya pada organisasi atau perusahaan. Human capital, capital employed, dan structural capital merupakan komponen pembentuk dari intellectual capital. Metode yang dikembangkan Pulic terkait intellectual capital disebut VAIC ${ }^{\mathrm{TM}}$ (Value Added Intellectual Coefficient). Metode ini relatif mudah digunakan karena data yang diperlukan terdapat pada laporan keuangan perusahaan, seperti neraca, laba rugi, dan catatan atas laporan keuangan.

Menurut Kartika dan Hatane (2013), hasil pengukuran yang dilakukan atas ketiga komponen intellectual capital menunjukkan bahwa terdapat pengaruh yang signifikan terhadap profitabilitas. Apabila semakin baik 
perusahaan dalam mengelola ketiga komponen intellectual capital, maka dapat menunjukkan semakin baik perusahaan dalam mengelola aset. Apabila perusahaan dapat mengelola aset dengan baik serta mampu menekan biaya operasional, maka nilai tambah (value added) perusahaan dapat meningkat yang merupakan hasil atas kemampuan intelektual perusahaan. Berdasarkan uraian tersebut, maka penelitian ini dapat dirumuskan hipotesis sebagai berikut:

Hipotesis 1: Intellectual Capital (IC) berpengaruh terhadap profitabilitas.

Kerangka pemikiran yang mendasari penelitian ini adalah sebagai berikut:

\section{Gambar 1}

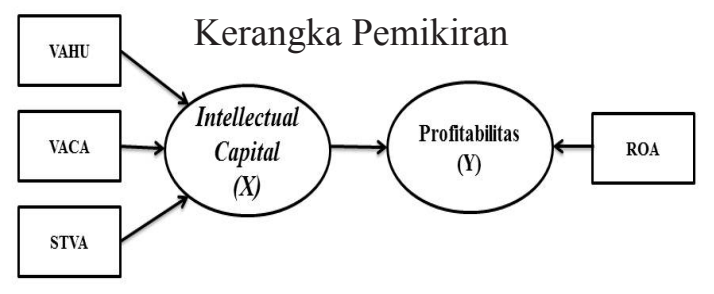

\section{Metode}

\section{Identifikasi Variabel}

Berdasarkan landasan teori dan hipotesis yang telah dijelaskan,maka variabel untuk penelitian yaitu variabel dependen merupakan variabel yang dipengaruhi oleh variabel independennya. Varibel dependen pada penelitian ini adalah Profitabilitas. Indikator dalam pengukuran profitabilitas menggunakan Return On Asset (ROA). Variabel independen merupakan variabel yang dapat memengaruhi variabel dependen. Variabel independen pada penelitian ini adalah intellectual capital (IC), dimana intellectual capital ini memiliki indikator sebagai berikut:
a. VAHU (Value Added Human Capital).
b. VACA (Value Added Capital Employed)
c. STVA (Structural Capital Value Added)

\section{Definisi Operasional dan Pengukuran Variabel}

\section{Profitabilitas}

Profitabilitasmerupakansuatupengukuran atas kemampuan perusahaan dalam menghasilkan laba. Dalam penelitian ini profitabilitas diukur dengan menggunakan rasio return on asset (ROA). Profitabilitas diukur menggunakan ROA (Return On Asset) karena ROA (Return On Asset) merupakan indikator yang dapat menggambarkan keberhasilan perusahaan dalam menghasilkan laba, sehingga semakin tinggi profitabilitas maka semakin tinggi kemampuan perusahaan dalam menghasilkan laba (Rachmawati, 2012). Return On Asset (ROA) digunakan untuk menghitung kelebihan return dari tangible asset milik perusahaan dan mengasumsikannya sebagai intangible asset untuk dihitung sebagai intellectual capital (Ulum, 2009 : 33).

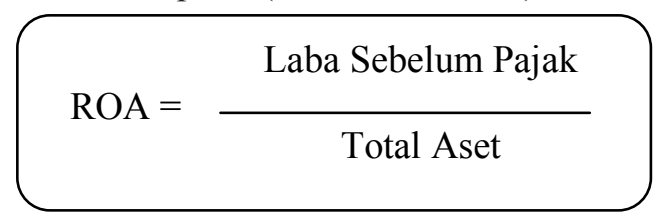

\section{Intellectual Capital}

Variabel independen dari penelitian ini adalah intellectual capital (IC) yang diukur dengan instrumen Value Added Intellectual Coefficient (VAIC $\left.{ }^{\mathrm{TM}}\right)$. Value Added Intellectual Coefficient (VAIC ${ }^{\mathrm{TM}}$ ) dikembangkan oleh Pulic di tahun 1998. Pada Value Added Intellectual Coefficient terdapat tiga komponen koefisien efisiensi pembentuk intellectual capital yang harus dihitung terlebih dahulu yaitu human capital (HC), capital employed (CE), dan structural capital(ST). Value Added Intellectual Coefficient (VAIC ${ }^{\mathrm{TM}}$ ) mengindikasikan kemampuan intelektual perusahaan dapat dianggap sebagai Business Performance Indicator - BPI (Ulum, 2009 : 90). Cara menghitung VAIC $^{\mathrm{TM}}$ (Value Added Intellectual Coefficient) adalah dengan menjumlahkan ketiga komponen koefisien efisiensi pembentuk intellectual capital. Rumus perhitungan VAIC ${ }^{\mathrm{TM}}$ (Value Added Intellectual Coefficient) adalah sebagai berikut:

$$
\mathrm{VAIC}^{\mathrm{TM}}=\mathrm{VAHU}+\mathrm{VACA}+\mathrm{STVA}
$$

Keterangan :

$\mathrm{VAIC}^{\mathrm{TM}}=$ Value Added Intellectual Coefficient 
VAHU = Value Added Human Capital

VACA = Value Added Capital Employed

STVA = Structural Capital Value Added

Agar dapat melakukan pengukuran terhadap VAIC $^{\mathrm{TM}}$ (Value Added Intellectual Coefficient) terlebih dahulu perlu melakukan perhitungan terhadap ketiga komponen intellectual capital yaitu VAHU (Value Added Human Capital), VACA (Value Added Capital Employed), dan STVA(Structural Capital Value Added). Langkahlangkah perhitungan atas ketiga komponen intellectual capital adalah sebagai berikut:

\section{VAHU (Value Added Human Capital).}

VAHU (Value Added Human Capital) menunjukkan berapa banyak VA (Value Added) dapat dihasilkan dengan dana yang dikeluarkan untuk tenaga kerja. Rasio ini menunjukkan kontribusi yang dibuat oleh setiap rupiah yang diinvestasikan dalam HC (Human Capital) terhadap value added perusahaan (Ulum, 2009: 86-90).

$$
\begin{aligned}
& \mathrm{VA}=\mathrm{OUT}-\mathrm{IN} \\
& \mathrm{VAHU}=\mathrm{VA} / \mathrm{HC}
\end{aligned}
$$

Dimana:

Output (OUT)

$=$ Pendapatan dan pendapatan lain.

Input (IN)

VA

$=$ Total biaya dan beban operasional dikurangi

$=$ Beban karyawan. Selisih antara Output dan Input.

Human Capital $(\mathrm{HC})$ = Beban karyawan.

\section{VACA (Value Added Capital Employed)}

VACA (Value Added Capital Employed) adalah indikator untuk VA (value added) yang diciptakan oleh satu unit dari physical capital. Rasio ini menunjukkan kontribusi yang dibuat oleh setiap unit dari CE (capital employed) terhadap value added perusahaan (Ulum, 2009: 86-90).

$$
\begin{aligned}
& \mathrm{VA}=\mathrm{OUT}-\mathrm{IN} \\
& \mathrm{VACA}=\mathrm{VA} / \mathrm{CE}
\end{aligned}
$$

\begin{tabular}{|c|c|}
\hline Input (IN) & $\begin{aligned}= & \text { Total biaya dan beban } \\
& \text { operasionaldikurangi } \\
& \text { beban karyawan. }\end{aligned}$ \\
\hline VA & $\begin{aligned}= & \text { Selisih antara Output } \\
& \text { dan Input. }\end{aligned}$ \\
\hline
\end{tabular}

Dimana:

Output $(\mathrm{OUT})=$ Pendapatan dan pendapatan lain.

\section{STVA (Structural Capital Value Added)}

STVA (Structural Capital Value Added) mengukur jumlah SC (structural capital) yang dibutuhkan untuk menghasilkan satu rupiah dari VA (value added) dan merupakan indikasi bagaimana keberhasilan SC (structural capital) dalam penciptaan nilai (Ulum, 2009: 86-90).

$$
\begin{array}{ll}
\mathrm{VA} & =\mathrm{OUT}-\mathrm{IN} \\
\mathrm{STVA} & =\mathrm{SC} / \mathrm{VA}
\end{array}
$$

\section{Dimana:}

Output (OUT)

$=$ Pendapatan dan pendapatan lain.

Input (IN)

$=$ Total biaya dan beban operasional dikurangi beban karyawan.

VA $=$ Selisih antara Output dan Input.

Structural Capital $(\mathrm{SC})=\mathrm{VA}-\mathrm{HC}$

\section{Populasi, Sampel dan Teknik Pengambilan Sampel}

Populasi yang digunakan dalam penelitian ini adalah perusahaan manufaktur yang terdaftar di Bursa Efek Indonesia (BEI). Sampel merupakan bagian dari populasi (Ulum et.al 2008). Teknik yang akan digunakan dalam pengambilan sampel adalah purposive sampling, dimana pemilihan sampel berdasarkan pada beberapa kriteria tertentu yang telah ditetapkan oleh peneliti. Kriteria sampel yang ditetapkan oleh peneliti adalah sebagai berikut:

1. Perusahaan yang selalu listed di Bursa Efek Indonesia (BEI) selama tahun 2010 - 2013.

2. Perusahaan yang melaporkan laporan keuangannya menggunakan mata uang rupiah.

3. Perusahaan memiliki nilai laba positif selama 
tahun 2010-2013 yang berarti perusahaan tidak mengalami kerugian selama tahun 2010-2013.

\section{Data dan Metode Pengumpulan Data}

Data yang digunakan dalam penelitian ini adalah data sekunder. Sumber data penelitian ini adalah laporan keuangan dari setiap perusahaan yang bergerak di sektor manufaktur dan telah diaudit oleh auditor independen. Data yang akan diolah juga akan disesuaikan dengan kriteria yang telah ditetapkan oleh peneliti. Data yang digunakan diperoleh melalui website Bursa Efek Indonesia (BEI) yaitu www.idx.co.id.

Metode yang akan dilakukan dalam penelitian ini menggunakan metode arsip, dimana data akan diperoleh melalui laporan keuangan perusahaan yang bertujuan untuk mendapatkan informasi yang diperlukan penelitimelalui laporan keuangan tersebut. Pengumpulan data dianggap selesai apabila data telah disesuaikan dengan kriteria yang telah ditetapkan oleh peneliti. Hal ini bertujuan untuk menyeleksi data yang diperlukan serta mendukung permasalahan dan topik yang akan dijadikan pada fokus penelitian ini.

\section{Metode Analisis Data}

Metode analisis data yang digunakan adalah metode partial least squares (PLS). Analisis data ini digunakan untuk menguji pengaruh Intellectual Capital (IC) dengan komponen pembentuk yaitu VAHU (Value Added Human Capital), VACA (Value Added Capital Employed), dan STVA (Structural Capital Value Added) terhadap profitabilitas. Tahapan dalam penelitian ini adalah sebagai berikut:

\section{Statistik Deskriptif}

Dalam pengujian statistik deskriptif menunjukkan jumlah data, nilai minimum, nilai maksimum, nilai means, dan nilai standar deviasi atas variabel independen yaitu VAIC $^{\mathrm{TM}}$ (Value Added Intellectual Coefficient) dan komponenkomponen yang membentuknya, yaitu: VAHU (Value Added Human Capital), VACA (Value Added Capital Employed), dan STVA (Structural Capital Value Added) serta variabel dependen yaitu profitabilitas yang menggunakan komponen
ROA (Return On Asset) untuk periode tahun 2010 sampai dengan tahun 2013 (Ulum et.al 2008).

\section{Uji Outer Model}

Indikator formatif pada dasarnya merupakan hubungan regresi dari indikator ke konstruk, maka cara menilainya adalah dengan melihat nilai koefisien regresi dan signifikansi dari koefisien regresi tersebut (Ulum et.al 2008). Antara konstruk dan indikator formatif diasumsikan bahwa setiap indikatornya dapat menjelaskan karakteristik domain konstruknya. Arah indikator formatif adalah dari indikator ke arah konstruk. Apabila terjadi kesalahan dalam pengukuran, maka kesalahan pengukuran hanya ditujukan pada konstruk dan tidak pada indikator, sehingga pengujian validitas dan reliabilitas pada konstruk tidak diperlukan (Ghozali dan Latan 2012 : 60).

Pada uji outer model dapat dilakukan evaluasi dengan melihat nilai signifikansi weight t-statistik. Sehingga dalam memperoleh nilai signifikansi weight harus melalui prosedur resampling atau bootstrapping. Apabila nilai signifikansi weight t-statistics $>1,96$ maka indikator konstruk adalah valid (Ghozali dan Latan 2012 : 81-82). Pada hasil uji outer model untuk model formatif dapat digunakan untuk mengetahui keandalan indikator, artinya dapat mengetahui indikator yang digunakan memiliki kontribusi yang kuat atau lemah dalam membangun atau mendukung konsep pengukuran konstruk.

\section{Uji Inner Model}

Pengujian inner model atau model struktural dilakukan untuk melihat hubungan antara konstruk, nilai signifikansi dan R-square dari model penelitian. Model struktural dievaluasi dengan menggunakan R-square untuk konstruk dependen dan uji t (Ulum et.al 2008).

$\mathrm{R}$-squares digunakan untuk menilai model kerangka pemikiran melalui Partial Least Squares (PLS) untuk setiap variabel dependen. Hasil R-squares menunjukkan jumlah variance dari konstruk yang dijelaskan oleh model. Apabila nilai R-squares menunjukkan 0.75 maka model dikatakan kuat. Selain itu, apabila nilai 
Tabel 1.

Descriptive Statistics

\begin{tabular}{lccccc}
\hline & $\mathbf{N}$ & Minimum & Maximum & Mean & Std. Deviation \\
\hline VAHU & 58 & 1.198 & 6.778 & 3.21871 & 1.619238 \\
VACA & 58 & .124 & 1.807 & .45609 & .348753 \\
STVA & 58 & .155 & .850 & .58900 & .194772 \\
VAIC & 58 & 1.646 & 8.894 & 4.26364 & 1.938286 \\
Valid N & 58 & & & & \\
(listwise) & & & & & \\
\hline
\end{tabular}

R-squares menunjukkan 0.50 Pengujian hipotesis dapat dilihat dari maka model dikatakan moderate. Jika nilai R-squares menunjukkan 0.25 maka model dikatakan lemah (Ghozali dan Latan 2012 : 82). hasil uji t, sehingga hipotesis dapat dinyatakan ditolak atau diterima melalui nilai dari t-statistic pada inner model. Pada hasil uji t, apabila t-hitung $>$ t-tabel, yaitu 1.96, maka Ha diterima (Ghozali dan Latan 2012 : 85).

\section{Hasil Penelitian dan Pembahasan}

\section{Statistik Deskriptif}

Analisis statistik deskriptif digunakan untuk menjelaskan jumlah sampel yang digunakan dalam penelitian ini. Jumlah sampel pada penelitian ini sebanyak 58 perusahaan manufaktur dari 138 perusahaan manufaktur yang terdaftar di Bursa Efek Indonesia (BEI). Pada statistik deskriptif dapat memberikan informasi terhadap obyek penelitian yang terdapat di Tabel 1 dan 2 yaitu informasi nilai minimum, maximum, ratarata, dan standar deviasi pada variabel independen dan dependen. Pada penelitian ini menggunakan variabel independen yaitu intellectual capital dan variabel dependen menggunakan profitabilitas. Pengolahan data statistik deskriptif menggunakan software IBM SPSS versi 20. Analisis statistik deskriptif dijelaskan sebagai berikut ini:

\section{Deskriptif indikator intellectual capital}

Berdasarkan Tabel 1 bahwa jumlah sampel yang dianalisis dalam statistik deskriptif berjumlah 58 perusahaan manufaktur. VAHU
(Value Added Human Capital) memiliki nilai minimum 1.198 yang terdapat pada PT. Kedaung Indah Can Tbk dan nilai maksimum 6.778 terdapat pada PT. Gunawan Dianjaya Steel Tbk. Nilai minimum VACA (Value Added Capital Employed) sebesar 0.124 yang terdapat pada PT. Jaya Pari Steel Tbk dan nilai maksimum sebesar 1.807 yang terdapat pada PT. Multi Bintang Indonesia Tbk. STVA (Structural Capital Value Added) memiliki nilai minimum sebesar 0.155 yang terdapat pada PT. Kedaung Indah Can Tbk dan nilai maksimum sebesar 0.850 yang terdapat pada PT. Indocement Tunggal Prakarsa Tbk.

Berdasarkan nilai rata-rata yang telah diketahui pada statistik deskriptif menunjukkan bahwa nilai rata-rata lebih besar daripada standar deviasi dimana nilai rata-rata VAHU (Value Added Human Capital) sebesar 3,219 $\geq 1,619$ yang merupakan standar deviasi dari VAHU (Value Added Human Capital).

Nilai rata-rata VAHU menjelaskan bahwa setiap 1 rupiah yang diinvestasikan pada beban karyawan mampu menghasilkan laba diluar beban karyawan sebesar 3,219 kali. Pada nilai rata-rata VACA (Value Added Capital Employed) dan standar deviasi VACA (Value Added Capital Employed) menunjukkan nilai sebesar $0,456 \geq$ 0,349 . Nilai rata-rata VACA menjelaskan bahwa setiap 1 rupiah yang diinvestasikan pada ekuitas mampu menghasilkan laba diluar beban karyawan sebesar 0,456 kali. Pada nilai rata-rata STVA (Structural Capital Value Added) dan standar deviasi STVA (Structural Capital Value 
Tabel 2.

Descriptive Statistics

\begin{tabular}{lccccc}
\hline & $\mathrm{N}$ & Minimum & Maximum & Mean & Std. Deviation \\
\hline ROA & 58 & .014 & .642 & .15547 & .125598 \\
$\begin{array}{l}\text { Valid N } \\
\text { (listwise) }\end{array}$ & 58 & & & & \\
\hline
\end{tabular}

Added) menunjukkan nilai sebesar 0,589 $\geq$ 0,195. Nilai rata-rata STVA menjelaskan bahwa setiap 1 rupiah laba diluar beban karyawan yang akan diinvestasikan oleh perusahaan mampu mencadangkan sarana dan prasarana bagi karyawan sebesar 0,589 kali. Jadi sebaran data yang digunakan penelitian ini tergolong baik dan tidak terlalu banyak variasi karena rata-rata dari VAHU, VACA, dan STVA $\geq$ standar deviasi VAHU, VACA, dan STVA.

Berdasarkan nilai rata-rata $\mathrm{VAIC}^{\mathrm{TM}}$ (Value Added Intellectual Coefficient) yang telah diketahui pada statistik deskriptif menunjukkan bahwa nilai rata-rata sebesar 4,264 lebih besar daripada standar deviasi dengan nilai sebesar 1,938, sehingga sebaran data pada VAIC ${ }^{\text {TM }}$ tergolong baik karena tidak terlalu banyak variasi. Nilai rata-rata VAIC ${ }^{\mathrm{TM}}$ diperoleh dari penjumlahan VAHU (Value Added Human Capital), VACA (Value Added Capital Employed), dan STVA (Structural Capital Value Added) secara berturut-turut sebesar 3,219; 0,$456 ; 0,589$ sehingga diperoleh rata-rata $\mathrm{VAIC}^{\mathrm{TM}}$ sebesar 4,264 yang menunjukkan bahwa ratarata perusahaan manufaktur telah berkontribusi terhadap intellectual capital sebesar 4,264. Nilai VAIC $^{\mathrm{TM}}$ minimum adalah 1,646 yang terdapat pada PT. Sierad Produce Tbk. Untuk nilai VAIC ${ }^{\text {TM }}$ maksimum adalah 8,894 yang terdapat pada PT. Unilever Indonesia Tbk.

\section{Deskriptif indikator profitabilitas}

Berdasarkan Tabel 2 menunjukkan bahwa jumlah sampel yang dianalisis dalam statistik deskriptif berjumlah 58 perusahaan. Pada Tabel 2 menggambarkan deskripsi variabel-variabel penelitian dalam menguji intellectual capital terhadap profitabilitas yang diukur menggunakan ROA (Return On Asset). Berdasarkan hasil ratarata ROA (Return On Asset) diketahui sebesar 0,155 lebih besar daripada standar deviasi yang bernilai 0,126 sehingga menunjukkan bahwa sebaran data ROA (Return On Asset) tergolong baik dikarenakan tidak terlalu banyak variasi. Nilai rata-rata ROA menjelaskan bahwa setiap 1 rupiah yang total aset yang dimiliki perusahaan mampu menghasilkan laba sebelum pajak sebesar 0,126 kali. Pada nilai minimum ROA (Return On Asset) sebesar 0,014 yang terdapat pada PT. Prima Alloy Steel Universal Tbk, sedangkan nilai maksimum ROA (Return On Asset) sebesar 0,642 terdapat pada PT. Multi Bintang Indonesia Tbk.

Pada penelitian ini diperluas dengan adanya pengujian sebelum dan sesudah implementasi IFRS (International Financial Reporting Standards) secara mandatory yang dilakukan dengan pertimbangan bahwa terdapat perubahan regulasi terkait penyajian laporan keuangan terutama pada penyajian laba. Sementara laba merupakan bagian penting dalam penilaian value added (VA). Pengujian per sektor industri bertujuan untuk melakukan analisis secara mendalam dan membuktikan konsistensi hasil pada model utama dalam pengujian ini. Hasil pengujianmenunjukkanbahwasecarakeseluruhan sektor industri manufaktur sebelum dan setelah implementasi IFRS (International Financial Reporting Standards) membuktikan hasil yang konsisten dengan model utama. Sementara untuk per sektor industri sebelum implementasi IFRS secara mandatory terdapat 2 sektor industri manufaktur yang tidak berpengaruh yaitu sektor semen dan plastik kemasan. Sedangkan pengujian setelah imlementasi IFRS 
Tabel 3.

Outer Weights (T-Values)

\begin{tabular}{lccccc}
\hline & $\begin{array}{c}\text { Original Sample } \\
(\mathbf{O})\end{array}$ & $\begin{array}{c}\text { Sample } \\
\text { Mean (M) }\end{array}$ & $\begin{array}{c}\text { Standard } \\
\text { Deviation } \\
(\text { STDEV) }\end{array}$ & $\begin{array}{c}\text { Standard } \\
\text { Error } \\
(\text { STERR) }\end{array}$ & $\begin{array}{c}\text { T Statistics } \\
(\mid \mathbf{O} / \text { STERR } \mid)\end{array}$ \\
\hline ROA -> Profitabilitas & 1,000000 & 1,000000 & 0,000000 & & \\
$\begin{array}{l}\text { STVA -> Intellectual } \\
\text { Capital }\end{array}$ & 0,394106 & 0,401448 & 0,106592 & 0,106592 & 3,697335 \\
$\begin{array}{l}\text { VACA -> Intellectual } \\
\text { Capital }\end{array}$ & 0,765262 & 0,761583 & 0,036827 & 0,036827 & 20,779920 \\
$\begin{array}{l}\text { VAHU _> Intellectual } \\
\text { Capital }\end{array}$ & 0,091099 & 0,087668 & 0,092571 & 0,092571 & 0,984100 \\
\hline
\end{tabular}

menunjukkan hasil yang konsisten yaitu setiap sektor industri manufaktur memiliki adanya pengaruh intellectual capital terhadap profitabilitas.

Hasil konsistensi penelitian ini juga diperkuat pada pengujian per sektor industri selama 4 tahun (2010-2013) yang menunjukkan terdapat pengaruh intellectual capital terhadap profitabilitas. Jadi, secara keseluruhan penelitian ini terbukti konsisten dengan tidak adanya nilai negative pada nilai signifikansi, sehingga perluasan yang dilakukan pada penelitian ini merupakan temuan yang menarik dalam penelitian ini. Penjelasan penelitian ini akan dijelaskan lebih spesifik pada analisis uji outer model dan analisis uji inner model.

\section{Analisis Uji Outer Model}

Tabel 3 adalah seluruh sektor industri manufaktur 2010-2013, berdasarkan hasil outer weight yang melalui bootstrapping untuk seluruh sektor industri manufaktur periode 2010-2013 dapat dilihat terdapat nilai $\mathrm{t}$ statistics pada beberapa indikator konstruk formatif yang valid dan tidak valid. Indikator konstruk formatif yang valid adalah STVA (Structural Capital Value Added) dan VACA (Value Added Capital Employed) karena STVA memiliki nilai sebesar 3,69 > 1,96 dan VACA memiliki nilai sebesar 20,77> 1,96 maka keduanya dinyatakan valid. Hal ini menunjukkan bahwa STVA (Structural
Capital Value Added) dan VACA (Value Added Capital Employed) memiliki kontribusi yang kuat dalam membangun atau mendukung konsep pengukuran intellectual capital. Sedangkan indikator VAHU (Value Added Human Capital) dinyatakan tidak valid karena VAHU memiliki nilai sebesar $0,984<1,96$. Hal ini menunjukkan bahwa VAHU (Value Added Human Capital) memiliki kontribusi yang lemah dalam membangun atau mendukung konsep pengukuran intellectual capital. Pada ROA (Return On Asset) tidak terdapat angka t-statistics dalam outer weight dikarenakan ROA merupakan satu satunya indikator formatif pada variabel dependen.

\section{Analisis Uji Inner Model}

Seluruh sektor industri manufaktur 20102013

Tabel 4.

R Square

\begin{tabular}{lc}
\hline & R Square \\
\hline Intellectual Capital & \\
Profitabilitas & 0.716993 \\
\hline
\end{tabular}

Pada Tabel 4 untuk tabel $\mathrm{R}$ square menunjukkan nilai $\mathrm{R}$ square untuk variabel profitabilitas sebesar 0.716993 yang berarti variabel profitabilitas termasuk dalam kategori moderate untuk seluruh sektor industrimanufaktur selama tahun 2010-2013. Hal ini dikarenakan $0,75 \geq \mathrm{R}$ square $\geq 0,50$. 
Tabel 5.

Inner Model T-Statistic

\begin{tabular}{lll}
\hline & $\begin{array}{l}\text { Intellectual } \\
\text { Capital }\end{array}$ & Profitabilitas \\
\hline $\begin{array}{l}\text { Intellectual } \\
\text { Capital }\end{array}$ & 27,300943 \\
Profitabilitas & & \\
\hline
\end{tabular}

Berdasarkan hasil uji inner model $t$ statistics pada Tabel 5 dengan menggunakan bootstrapping, variabel intellectual capital berpengaruh signifikan terhadap profitabilitas. Hal ini dikarenakan nilai yang dihasilkan sebesar $27,300943>1.96$ untuk seluruh sektor industri manufaktur pada tahun 2010-2013.

Tabel 6.

Pembahasan Hasil Uji Outer Model

\begin{tabular}{|c|c|c|c|c|c|c|c|c|c|c|c|}
\hline \multirow{3}{*}{ No } & \multirow{3}{*}{ Keterangan } & \multirow[t]{3}{*}{$\mathbf{N}$} & \multicolumn{3}{|c|}{ Komponen Utama } & \multicolumn{6}{|c|}{ Komponen Pendukung } \\
\hline & & & \multicolumn{3}{|c|}{ Keseluruhan (010-2013) } & \multicolumn{3}{|c|}{$\begin{array}{c}\text { Sebelum IFRS } \\
(2010-2011)\end{array}$} & \multicolumn{3}{|c|}{$\begin{array}{c}\text { Sesudah IFRS } \\
(2012-2013) \\
\end{array}$} \\
\hline & & & VAHU & VACA & STVA & VAHU & VACA & STVA & VAHU & VACA & STVA \\
\hline & $\begin{array}{l}\text { Seluruh } \\
\text { Sektor } \\
\text { Industri } \\
\end{array}$ & 58 & 0,984 & 20,780 & 3,697 & 0,050 & 13,240 & 3,901 & 1,649 & 14,817 & 1,542 \\
\hline \multicolumn{12}{|c|}{ Per Sektor Industri : } \\
\hline 1 & Semen & 3 & 0,613 & 2,320 & 0,735 & 0,221 & 1,311 & 1,142 & 0,023 & 0,071 & 0,058 \\
\hline 2 & $\begin{array}{l}\text { Keramik, } \\
\text { Porselen, } \\
\text { dan Kaca }\end{array}$ & 3 & 0,837 & 2,036 & 0,335 & 0,681 & 1,141 & 0,648 & 0,931 & 3,070 & 0,000 \\
\hline 3 & $\begin{array}{l}\text { Logam dan } \\
\text { Sejenisnya }\end{array}$ & 7 & 0,413 & 2,060 & 2,414 & 0,310 & 0,829 & 0,996 & 0,006 & 1,350 & 1,221 \\
\hline 4 & Kimia & 3 & 1,679 & 4,173 & 0,634 & 0,483 & 1,705 & 0,443 & 0,494 & 0,341 & 0,105 \\
\hline 5 & $\begin{array}{l}\text { Plastik dan } \\
\text { Kemasan }\end{array}$ & 4 & 0,293 & 5,862 & 0,660 & 1,131 & 1,412 & 1,394 & 3,522 & 6,648 & 2,579 \\
\hline 6 & $\begin{array}{l}\text { Pakan } \\
\text { Ternak }\end{array}$ & 4 & 0,909 & 1,234 & 1,303 & 0,773 & 2,062 & 1,862 & 0,132 & 0,965 & 2,426 \\
\hline 7 & $\begin{array}{l}\text { Otomotif } \\
\text { dan } \\
\text { Komponen }\end{array}$ & 9 & 1,618 & 8,249 & 3,657 & 1,085 & 2,759 & 2,488 & 0,130 & 6,173 & 0,671 \\
\hline 8 & Kabel & 3 & 2,123 & 1,448 & 0,704 & 3,604 & 0,813 & 1,480 & 0,092 & 0,006 & 0,027 \\
\hline 9 & $\begin{array}{l}\text { Makanan } \\
\text { dan } \\
\text { Minuman }\end{array}$ & 10 & 0,930 & 12,318 & 0,468 & 0,005 & 11,938 & 1,051 & 1,720 & 2,897 & 1,098 \\
\hline 10 & Rokok & 2 & 0,023 & 0,852 & 0,025 & 0,246 & 3,524 & 4,088 & 0,631 & 1,435 & 2,423 \\
\hline 11 & Farmasi & 6 & 2,265 & 7,564 & 1,055 & 1,834 & 3,737 & 0,222 & 0,310 & 3,165 & 1,764 \\
\hline 12 & $\begin{array}{l}\text { Kosmetik } \\
\text { dan barang } \\
\text { keperluan } \\
\text { rumah } \\
\text { tangga }\end{array}$ & 2 & 0,489 & 0,263 & 0,264 & 1,165 & 2,277 & 0,500 & 1,749 & 2,395 & 0,425 \\
\hline 13 & $\begin{array}{l}\text { Peralatan } \\
\text { Rumah } \\
\text { Tangga }\end{array}$ & 2 & 0,443 & 0,034 & 0,217 & 6,154 & 9,652 & 12,665 & 7,376 & 7,531 & 4,634 \\
\hline
\end{tabular}


Penelitian ini bertujuan untuk mengetahui pengaruh intellectual capital (IC) terhadap profitabilitas pada perusahaan manufaktur yang terdaftar di Bursa Efek Indonesia (BEI). Sampel penelitianiniterdiri dari58 perusahaan manufaktur yang terdaftar di Bursa Efek Indonesia (BEI). Pada penelitian ini dilakukan perluasan dengan menganalisis sebelum dan setelah implementasi IFRS (International Financial Reporting Standards) baik secara keseluruhan maupun per sektor industri manufaktur. Intellectual capital terdiri dari VAHU (Value Added Human Capital), VACA (Value Added Capital Employed), dan STVA (Structural Capital Value Added).

Pembahasan pertama untuk tabel hasil uji outer model dengan menganalisis nilai VAHU (Value Added Human Capital), VACA (Value Added Capital Employed), dan STVA (Structural Capital Value Added) atas variabel intellectual capital. VAHU (Value Added Human Capital) merupakan salah satu pengukuran indikator intellectual capital yang menunjukkan seberapa banyak value added (VA) yang dihasilkan perusahaan dengan dana yang dikeluarkan untuk tenaga kerja. VAHU (Value Added Human Capital) merupakan perbandingan antara VA (Value Added) dan HC (Human Capital). VA (Value Added) dapat diperoleh selisih antara Output dan Input. Output dapat diperoleh melalui total pendapatan dan pendapatan lain-lain. Input dapat diperoleh dari total biaya dan beban operasional dikurangi dengan beban karyawan. HC (Human Capital) merupakan beban karyawan yang mencakup gaji, upah, tunjangan, dan jasa tenaga ahli. Pada hasil penelitian secara keseluruhan sektor industri manufaktur tahun 2010-2013 menunjukkan nilai VAHU (Value Added Human Capital) sebesar 0,984 dimana VAHU (Value Added Human Capital) belum dapat menjelaskan intellectual capital dikarenakan nilai VAHU $\leq$ 1,96. Untuk hasil penelitian sebelum dan setelah implementasi IFRS (International Financial Reporting Standards) menunjukkan adanya peningkatan VAHU yaitu 0,050 menjadi 1,649. Kenaikan ini diikuti oleh beberapa sektor industri manufaktur yaitu sektor kimia, plastik dan kemasan, makanan dan minuman, rokok, kosmetik dan barang keperluan rumah tangga, dan peralatan rumah tangga.

VACA (Value Added Capital Employed) merupakan salah satu indikator pengukur intellectual capital yang menggambarkan setiap 1 unit ekuitas dalam menciptakan value added (VA) perusahaan. VACA (Value Added Capital Employed) merupakan perbandingan antara VA (Value Added) dan CE (Capital Employed). VA (Value Added) merupakan selisih dari output dan input. Output diperoleh dari total pendapatan dan pendapatan lain-lain. Sedangkan input diperoleh dari total biaya dan beban operasional dikurangi beban karyawan. CE (Capital Employed) dapat diperoleh dari total ekuitas perusahaan.

Sehinggapenelitianterhadap VACA(Value Added Capital Employed) secara keseluruhan untuk sektor industri manufaktur tahun 20102013 diperoleh nilai 20,780. Hal ini menunjukkan bahwa VACA (Value Added Capital Employed) merupakan indikator yang dapat menjelaskan intellectual capital dikarenakan nilai VACA $\geq 1,96$. Sedangkan untuk penelitian sebelum dan setelah implementasi IFRS (International Financial Reporting Standards), VACA (Value Added Capital Employed) memiliki peningkatan yaitu dengan nilai 13,240 menjadi 14,817. Kenaikan ini diikuti oleh beberapa sektor industri manufaktur yaitu sektor keramik, porselen, dan kaca; logam dan sejenisnya; plastik dan kemasan; otomotif dan komponen; dan kosmetik dan barang keperluan rumah tangga.

STVA merupakan salah satu indikator pengukur intellectual capital yang mengukur jumlah struktural capital yang dibutuhkan dalam menghasilkan satu rupiah dari value added (VA). STVA (Structural Capital Value Added) merupakan perbandingan antara ST (Structural Capital) dan VA (Value Added). ST (Structural Capital) dapat diperoleh melalui VA-HC. Sedangkan VA (Value Added) dapat diperoleh melalui output dan input. Output diperoleh melalui total pendapatan dan pendapatan lainlain. Input dapat diperoleh melalui total biaya dan beban operasional dikurangi beban karyawan.

Pada penelitian ini menunjukkan bahwa STVA (Structural Capital Value Added) 
Tabel 7

Pembahasan Hasil Uji Inner Model

\begin{tabular}{|c|c|c|c|c|c|c|c|c|}
\hline \multirow{3}{*}{ No } & \multirow{3}{*}{ Keterangan } & \multirow{3}{*}{$\mathbf{N}$} & \multirow{2}{*}{\multicolumn{2}{|c|}{$\begin{array}{c}\text { Komponen Utama } \\
\text { Keseluruhan } \\
(2010-2013)\end{array}$}} & \multicolumn{4}{|c|}{ Komponen Pendukung } \\
\hline & & & & & \multicolumn{2}{|c|}{$\begin{array}{c}\text { Sebelum IFRS } \\
(2010-2011)\end{array}$} & \multicolumn{2}{|c|}{$\begin{array}{c}\text { Sesudah IFRS } \\
(2012-2013)\end{array}$} \\
\hline & & & R Square & t - Hitung & R Square & t - Hitung & R Square & t - Hitung \\
\hline & $\begin{array}{l}\text { Seluruh } \\
\text { Sektor } \\
\text { Industri }\end{array}$ & 58 & 0,717 & 27,301 & 0,683 & 17,228 & 0,749 & 19,853 \\
\hline \multicolumn{9}{|c|}{ Per Sektor Industri : } \\
\hline 1 & Semen & 3 & 0,964 & 7,829 & 0,999 & 1,765 & 0,946 & 12,211 \\
\hline 2 & $\begin{array}{l}\text { Keramik, } \\
\text { Porselen, dan } \\
\text { Kaca }\end{array}$ & 3 & 0,788 & 2,229 & 0,965 & 17,212 & 0,981 & 10,291 \\
\hline 3 & $\begin{array}{l}\text { Logam dan } \\
\text { Sejenisnya }\end{array}$ & 7 & 0,554 & 13,085 & 0,482 & 3,302 & 0,614 & 9,288 \\
\hline 4 & Kimia & 3 & 0,965 & 122,812 & 0,994 & 20,209 & 0,980 & 11,548 \\
\hline 5 & $\begin{array}{l}\text { Plastik dan } \\
\text { Kemasan }\end{array}$ & 4 & 0,905 & 10,837 & 0,930 & 1,752 & 0,961 & 55,925 \\
\hline 6 & Pakan Ternak & 4 & 0,638 & 6,458 & 0,710 & 11,943 & 0,877 & 3,815 \\
\hline 7 & $\begin{array}{l}\text { Otomotif dan } \\
\text { Komponen }\end{array}$ & 9 & 0,756 & 16,584 & 0,630 & 4,840 & 0,897 & 22,692 \\
\hline 8 & Kabel & 3 & 0,952 & 38,773 & 0,992 & 43,955 & 0,945 & 20,950 \\
\hline 9 & $\begin{array}{l}\text { Makanan dan } \\
\text { Minuman }\end{array}$ & 10 & 0,844 & 31,112 & 0,908 & 24,087 & 0,877 & 23,943 \\
\hline 10 & Rokok & 2 & 0,997 & 6,202 & 1,000 & 12,251 & 1,000 & 9,156 \\
\hline 11 & Farmasi & 6 & 0,980 & 250,803 & 0,996 & 7,920 & 0,987 & 11,149 \\
\hline 12 & $\begin{array}{l}\text { Kosmetik } \\
\text { dan barang } \\
\text { keperluan } \\
\text { rumah tangga }\end{array}$ & 2 & 0,998 & 8,115 & 1,000 & 7,624 & 1,000 & 7,092 \\
\hline 13 & $\begin{array}{l}\text { Peralatan } \\
\text { Rumah Tangga }\end{array}$ & 2 & 0,774 & 17,306 & 1,000 & 7,119 & 1,000 & 15,502 \\
\hline
\end{tabular}

secara keseluruhan untuk semua sektor industri manufaktur tahun 2010-2013 memiliki nilai sebesar 3,697. Hal ini menunjukkan bahwa STVA (Structural Capital Value Added) mampu menjelaskan intellectual capital dikarenakan nilai STVA $\geq 1,96$. Penelitian ini juga meneliti sebelum dan setelah implementasi IFRS dimana STVA (Structural Capital Value Added) mengalami penurunan yaitu dengan nilai 3,901 menjadi 1,542. Penurunan STVA (Structural Capital Value Added) diikuti oleh beberapa sektor industri manufaktur yaitu sektor semen; keramik, porselen, dan kaca; kimia; otomotif dan komponen; kabel; rokok; dan peralatan rumah tangga. Pada penelitian ini menunjukkan bahwa VAHU (Value Added Human Capital) memiliki kontribusi yang lemah dalam membangun serta mendukung konsep intellectual capital.

Hal ini didukung oleh penelitian dari Martha Kartika dan Saarce Elsye Hatane (2013) dimana menunjukkan bahwa VAHU tidak berpengaruh signifikan terhadap profitabilitas. Sedangkan penelitian dari Kirmizi Ritonga dan Jessica Andriyanie (2011); Daniel Zeghal dan Anis Maaloul (2010); Ihyaul Ulum, Imam Ghozali, dan Anis Chariri (2008) menunjukkan bahwa 
VAHU (Value Added Human Capital) memiliki kontribusi yang kuat terhadap intellectual capital. Sehingga VAHU menunjukkan hasil yang tidak konsisten dikarenakan adanya perbedaan metode dan data yang digunakan setiap peneliti. Penelitian ini menunjukkan bahwa VACA (Value Added Capital Employed) memiliki kontribusi yang kuat dalam membangun serta mendukung konsep intellectual capital. Hasil penelitian VACA telah dibuktikan dari penelitian terdahulu yaitu Martha Kartika dan Saarce Elsye Hatane (2013), Kirmizi Ritonga dan Jessica Andriyanie (2011), dan Daniel Zeghal dan Anis Maaloul (2010). Sehingga hasil VACA menunjukkan hasil yang cukup konsisten meskipun adanya perbedaan metode dan data yang digunakan oleh setiap peneliti. VACA mampu menunjukkan bahwa terdapat kontribusi yang kuat dalam mendukung serta membangun konsep intellectual capital.

Penelitian ini juga menunjukkan hasil STVA (Structural Capital Value Added) memiliki kontribusi yang kuat dalam membangun serta mendukung konsep intellectual capital. Hasil penelitian ini mendukung penelitian terdahulu yaitu Martha Kartika dan Saarce Elsye Hatane (2013); Daniel Zeghal dan Anis Maaloul (2010). Hal ini menunjukkan bahwa hasil STVA tidak cukup konsisten dalam berkontribusi untuk membangun serta mendukung konsep intellectual capital. Sehingga perbedaan metode dan data yang digunakan setiap peneliti mampu mengubah hasil dari STVA seperti pada Tabel 7.

Pada pembahasan kedua ini yaitu membahas hasil dari uji inner model yang terdiri dari $\mathrm{R}$ square dan t-hitung. Hasil dari R square menentukan bahwa model dapat dikatakan kuat, moderate, atau lemah. Sedangkan t-Hitung menunjukkan adanya pengaruh atau tidak antar variabel. Pada seluruh sektor industri manufaktur di tahun 2010-2013 menunjukkan nilai R square adalah moderate sebesar 0,717 karena $0,75 \geq R$ square $\geq 0,50$. Hal ini didukung oleh beberapa sektor industri yang memiliki hasil $\mathrm{R}$ square moderate yaitu sektor logam dan sejenisnya serta pakan ternak. Adapun beberapa sektor industri manufaktur yang menunjukkan bahwa $\mathrm{R}$ square $\geq 0,75$ dimana $\mathrm{R}$ square diaktakan kuat yaitu sektor semen; keramik, porselen, dan kaca; kimia; plastik dan kemasan; otomotif dan komponen; kabel; makanan dan minuman; rokok; farmasi; kosmetik dan barang keperluan rumah tangga; dan perlatan rumah tangga.

Pada setiap sektor industri manufaktur tidak ada yang menunjukkan hasil $\mathrm{R}$ square yang lemah atau $R$ square $\leq 0,25$. Nilai $R$ square tertinggi untuk tahun 2010-2013 terdapat pada sektor industri kosmetik dan barang keperluan rumah tangga dengan nilai 0,998 yang artinya model kuat karena $\mathrm{R}$ square $\geq 0,75$.

Hasil R square menunjukkan peningkatan yang artinya model dari kerangka pemikiran semakin baik. Hal ini dapat dilihat pada tahun sebelum dan setelah implementasi IFRS. Pada tahun 2010-2011 seluruh sektor industri manufaktur menunjukkan hasil R square sebesar 0,683 yang artinya model moderate karena 0,75 $\geq R$ square $\geq 0,50$. Nilai $R$ square tertinggi untuk tahun 2010-2011 terdapat pada sektor industri rokok; kosmetik dan barang keperluan rumah tangga; dan peralatan rumah tangga dengan nilai sebesar 1,00 yang artinya model kuat karena $R$ square $\geq 0,75$. Pada tahun 2012-2013 seluruh sektor industri manufaktur menunjukkan peningkatan $\mathrm{R}$ square menjadi 0,749 yang artinya model dikatakan kuat karena $\mathrm{R}$ square $\geq 0,75$. Nilai $R$ square tertinggi untuk tahun 2012-2013 terdapat pada sektor industri rokok; kosmetik dan barang keperluan rumah tangga; dan peralatan rumah tangga dengan nilai sebesar 1,00 yang artinya model kuat karena $\mathrm{R}$ square $\geq$ 0,75 . Peningkatan ini diikuti oleh beberapa sektor industri manufaktur seperti sektor keramik, porselen, dan kaca; logam dan sejenisnya; plastik dan kemasan; pakan ternak; serta otomotif dan komponen.

Pada hasil penelitian atas t-hitung dapat digunakan untuk menguji serta mengetahui pengaruh intellectual capital terhadap profitabilitas. Hasil t-hitung menunjukkan bahwa terdapat pengaruh intellectual capital terhadap profitabilitas pada perusahaan manufaktur tahun 2010-2013. Hal ini dapat diketahui melalui nilai t-Hitung sebesar 27,301 $\geq 1,96$ yang artinya hipotesis diterima atau terdapat pengaruh 
yang signifikan intellectual capital terhadap profitabilitas pada perusahaan manufaktur tahun 2010-2013. Nilai signifikansi tertinggi tahun 2010-2103 V diperoleh sektor industri farmasi dengan nilai signifikansi sebesar 250,803.

Penelitian ini juga menunjukkan adanya peningkatan nilai signifikansi t- Hitung sebelum dan setelah implementasi IFRS. Pada tahun 20102011 nilai signifikansi t-Hitung sebesar 17,228 dan terjadi peningkatan di tahun 2012-2013 sebesar 19,853. Peningkatan nilai signifikansi atas t-Hitung ini diikuti oleh beberapa sektor industri yaitu sektor semen; logam dan sejenisnya; plastik dan kemasan; otomotif dan komponen; farmasi; dan peralatan rumah tangga. Hal ini menunjukkan bahwa sektor industri yang memiliki kenaikan nilai signifikansi t-hitung memiliki motivasi untuk mengembangkan intellectual capital yang dimiliki perusahaan dalam meningkatkan profitabilitas serta kepentingan stakeholder.

Pada penelitian ini telah dibuktikan oleh beberapa penelitian terdahulu dimana intellectual capital memiliki pengaruh tidak hanya terhadap profitabilitas tetapi terhadap kinerja keuangan perusahaan. Penelitian terdahulu yang telah membuktikan adanya pengaruh intellectual capital terhadap profitabilitas yaitu Martha Kartika dan Saarce Elsye Hatane (2013) dengan menggunakan SPSS. Sedangkan penelitian terdahulu yang telah membuktikan adanya pengaruh intellectual capital terhadap kinerja keuangan perusahaan yaitu Kirmizi Ritonga dan Jessica Andriyanie (2011); Daniel Zeghal dan Anis Maaloul (2010); dan Ihyaul Ulum, Imam Ghozali, dan Anis Chariri (2008).

Berdasarkan teori dasar penelitian ini yaitu stakeholder theory menunjukkan bahwa stakeholder memiliki kepentingan dalam memengaruhi manajemen dalam proses pemanfaatan potensi yang dimiliki perusahaan. Pengelolaan atas potensi yang dimiliki organisasi secara baik dan optimal dapat menciptakan nilai tambah (value added) serta dapat meningkatkan kinerja keuangan perusahaan termasuk profitabilitas yang hal tersebut merupakan tujuan para stakeholder dalam mengintervensi manajemen. Penelitian ini menunjukkan intellectual capital (IC) berpengaruh terhadap profitabilitas, sehingga dapat disimpulkan bahwa stakeholder memiliki peran yang penting dalam pengelolaan sumber daya intelektual yang dimiliki perusahaan dimana hal ini dapat meningkatkan profitabilitas yang akan dihasilkan oleh perusahaan.

\section{Kesimpulan, Keterbatasan dan Implikasi Hasil Penelitian}

Penelitian ini dilakukan untuk menguji apakah intellectual capital yang diukur menggunakan metode VAIC ${ }^{\mathrm{TM}}$ (Value Added Intellectual Coefficient) berpengaruh terhadap profitabilitas perusahaan. Perusahaan yang digunakan pada penelitian ini adalah perusahaan yang bergerak di sektor manufaktur yang terdaftar di Bursa Efek Indonesia (BEI) untuk tahun 2010-2013. Pada penelitian ini tidak hanya bertujuan untuk mengetahui pengaruh intellectual capital (IC) terhadap profitabilitas perusahaan secara keseluruhan tetapi juga untuk mengetahui pengaruh intellectual capital terhadap profitabilitas pada setiap sektor industri manufaktur sebagai komponen pendukung. Setelah dilakukan analisis secara deskriptif maupun statistik pada penelitian ini, maka dapat diperoleh kesimpulan, keterbatasan, dan saran yang ditujukan kepada peneliti selanjutnya yang akan mengambil topik yang sama. Kesimpulan dari penelitian ini adalah sebagai berikut:

1. Setelah dilakukan tabulasi dan olah data dalam pengujian hipotesis, maka dapat disimpulkan bahwa intellectual capital (IC) berpengaruh terhadap profitabilitas secara keseluruhan pada perusahaan manufaktur yang terdaftar di Bursa Efek Indonesia (BEI) untuk tahun 2010-2013.

2. Pada hasil analisis data juga diperoleh bahwa intellectual capital (IC) berpengaruh terhadap profitabilitas sebelum dan sesudah implementasi IFRS (International Financial Reporting Standards) pada perusahaan manufaktur yang terdaftar di Bursa Efek Indonesia (BEI). Pengujian ini dilakukan bertujuan untuk memberikan informasi 
tambahan dari komponen pendukung atas komponen utama penelitian.

3. Pada pengujian setiap sektor industri manufaktur bertujuan untuk membuktikan konsistensi pengaruh intellectual capital terhadap profitabilitas, sehingga hasilnya adalah sektor industri semen dan sektor plastik kemasan yang menunjukkan bahwa intellectual capital (IC) tidak berpengaruh terhadap profitabilitas untuk tahun 20102011.

Pada penelitian ini masih memiliki sejumlah keterbatasan yang dialami peneliti selama melakukan penelitian. Keterbatasan ini diharapakan mampu memberikan evaluasi untuk peneliti selanjutnya yang akan mengambil topik yang sama yaitu "Beban gaji yang terdapat di laporan keuangan perusahaan belum dapat menjelaskan VAHU (Value Added Human Capital) berdasarkan landasan teori yang telah diuraikan. Beban gaji belum dapat memberikan informasi tentang kemampuan yang dimiliki sumber daya manusia seperti inovasi, komitmen, dan pembaharuan di dalam perusahaan. Sedangkan informasi tersebut tidak terdapat pada laporan keuangan perusahaan manufaktur yang terdaftar di Bursa Efek Indonesia (BEI)".

Saran yang terkait atas keterbatasan yang telah diungkapkan diharapkan mampu memberikan perbaikan bagi peneliti selanjutnya maupun bagi perusahaan, maka peneliti memberikan saran yaitu bagi perusahaan diharapkan untuk lebih menjelaskan laporan keuangan perusahaan secara lengkap terutama pada beban gaji yang diberikan kepada karyawan agar stakeholder dapat memahami nilai tambah yang terdapat pada sumber daya manusia yang bekerja di dalam perusahaan tersebut. Sedangkan saran bagi peneliti selanjutnya yaitu diharapkan untuk menambahkan variabel non-financial measurement sebagai indikator dalam intellectual capital, sehingga penelitian intellectual capital dapat digunakan untuk merumuskan strategi, menilai pelaksanaan strategi, strategi dalam pengembangan, diversifikasi, ekspansi, menentukan kompensasi karyawan, dan berkomunikasi dengan para stakeholder eksternal.

\section{Daftar Pustaka}

Ahangar, R. G. (2011). The relationship between intellectual capital and financial performance: An empirical investigation in an Iranian company. African Journal of Business Management, Vol. 5(1), pp. 88-95.

Bukh, P., Nielsen, C., Gormsen, P., \& Mouritsen, J. (2005). Disclosure of information on intellectual capital in Danish IPO prospectuses. Accounting, Auditing \& Accountability Journal, Vol. 18 No. 6. pp. 713-732.

Ghozali, I., \& Latan, H. (2012). SmartPLS 2.0 M3. Semarang: Badan Penerbit Universitas Diponegoro.

Kartika, M., \& Hatane, S. E. (2013). Pengaruh Intellectual Capital Terhadap Profitabilitas Perusahaan Perbankan yang Terdaftar di Bursa Efek Indonesia pada Tahun 20072011. Business Accounting Review, Vol.1, No.2, 14-25.

Pulic, A. (1998). Measuring the performance of intellectual potential in knowledge economy. Paper presented at the 2nd McMaster Word Congress on Measuring and Managing Intellectual Capital by the Austrian Team for Intellectual Potential.

Rachmawati, D. (2012). Pengaruh Intellectual Capital terhadap Return On Asset (ROA) Perbankan. Jurnal Nominal, Volume 1, 3440.

Ritonga, K., \& Andriyanie, J. (Juli 2011). Pengaruh Modal Intelektual Terhadap Kinerja Keuangan (Pada Perusahaan LQ45 yang Terdaftar di Bursa Efek Indonesia). Pekbis Jurnal, Vol. 3, No.2, 467-481.

Ulum, I. (2009). Intellectual Capital. Yogyakarta: Graha Ilmu.

Ulum, I. (November 2008). Intellectual Capital Performance Sektor Perbankan di Indonesia. Jurnal Akuntansi dan Keuangan, Vol. 10, No. 2, 77-84.

Ulum, I., \& Imam Ghozali dan Anis Chariri. (2008). Intellectual Capital Dan Kinerja 
Keuangan; SuatuAnalisis Dengan Pendekatan Partial Least Squares (PLS). Simposium Nasional Akuntansi 11 (SNA 11).

Zeghal, D., \& Maaloul, A. (2010). Analysing value added as an indicator of intellectual capital and its consequences on company performance. Journal of Intellectual Capital, 39-60. 